\title{
MISI DAN KEBANGKITAN ROHANI: IMPLIKASI MISI ALLAH BAGI GEREJA
}

\author{
Yosua Feliciano Camerling 1 \\ Mahasiswa Pascasarjana Sekolah Tinggi Filsafat Jaffray Makassar \\ yosuacamerling@gmail.com \\ Hengki Wijaya ${ }^{2}$ \\ Dosen Prodi Ilmu Filsafat Sekolah Tinggi Filsafat Jaffray Makassar \\ hengkiwijaya@sttjaffray.ac.id
}

\begin{abstract}
The purpose is to explain the close relationship between mission and spiritual awakening. The method used is qualitative description with library studies seen from the history of spiritual awakening that has happened and the Christian mission's understanding of spiritual awakening. In conclusion, spiritual awakening can revive the passion for mission, and it is one of the concrete steps manifested by missionaries in the event of a spiritual resurrection. For this reason, the signs that arise when spiritual awakening occurs are the heart of the mission involved. The relationship between mission and spiritual awakening is a spiritual awakening to evoke the spirit of mission. This is marked by so many missionaries who are engaged in missionary service.
\end{abstract}

Key words: mission, spiritual awakening, Great Commission, calling, Christianity

\begin{abstract}
Abstrak
Tujuan penulisan ini untuk menjelaskan hubungan yang erat antara misi dan kebangkitan rohani. Metode yang digunakan adalah kualitatif deskripsi dengan studi kepustakaan dilihat dari sejarah kebangkitan rohani yang pernah terjadi dan pemahaman misi Kristen terhadap kebangkitan rohani. Sebagai kesimpulannya adalah kebangkitan rohani dapat menghidupkan kembali gairah untuk bermisi, dan misi adalah salah satu langkah yang kongkret yang diwujudnyatakan oleh para misionaris ketikaterjadinya kebangkitan rohani. Untuk itu, tanda-tanda yang muncul saat kebangkitan rohani terjadi adalah hati misi ikut di dalamnya. Hubungan antara misi dan kebangkitan rohani ialah kebangkitan rohani membangkitkan semangat bermisi. Hal ini ditandai dengan begitu banyaknya misionaris yang terjun dalam pelayanan misi.
\end{abstract}

Kata kunci: misi, kebangkitan rohani, Amanat Agung, panggilan, Kristen

\section{Pendahuluan}

Jika berbicara mengenai misi artinya hal tersebut tak lepas dari kegiatan untuk menyebarluaskan berita Injil (kabar baik) dan mendirikan jemaat setempat yang dilaksanakan atas dasar pengutusan sebagai kelanjutan misi Kristus. Untuk itu, ada begitu banyak cara yang dapat dilakukan oleh gereja Tuhan yang dalam hal ini orang percaya untuk menunaikan Amanat Agung Yesus Kristus yang dikutip oleh Matius yang berbunyi: "Kepada-Ku telah diberikan segala kuasa di sorga dan di bumi. Karena itu pergilah, jadikanlah semua bangsa murid-Ku dan baptislah mereka dalam nama Bapa dan Anak dan 
Roh Kudus, dan ajarlah mereka melakukan segala sesuatu yang telah Kuperintahkan kepadamu. Dan ketahuilah, Aku menyertai kamu senantiasa sampai kepada akhir zaman." (Matius 28:18-20).

Perkataan Yesus ini merupakan pengajaran-Nya yang sangat tersohor ketika Ia datang ke dunia bahkan Christopher J. Wright mengatakan bahwa"versi Amanat Agung di akhir Injil Matius cenderung menempati posisi kehormatan." ${ }^{1}$ Maksudnya ialah bahwa nas ini sangat diagungkan, dan dipercayai bahwa gereja Tuhan harus mendalami dan bahkan harus pula mengaplikasikan nas ini dalam tindakan yang nyata sebagai kelanjutan misi Kristus. Namun pada kenyataannya, hal tersebut bukanlah perkara yang mudah untuk dilakukan. Ada begitu banyak tantangan dan hambatan yang datang dari dalam maupun dari luar gereja yang hendak mencoba untuk melumpuhkan keinginan untuk menunaikan tugas Amanat Agung ini.

Inilah juga yang dirasakan oleh gereja-gereja pada abad ke-16. Seorang misiolog bernama David Bosch mengatakan dalam bukunya bahwa begitu banyak gereja yang semakin takluk pada etos Pencerahan. Selain itu, Rasionalisme menjadi unggul di lingkungan teolog dan gerejawi. Bahkan akhir abad ke-18 Rasionalisme hamper sama sekali melumpuhkan keinginan untuk melakukan misi. ${ }^{2}$ Akibatnya gereja Tuhan mengalami kondisi spiritual yang suam-suam kuku bahkan tak dapat disangkal bila dikatakan bahwa gereja Tuhan sampai berada pada kondisi spiritual yang stagnan.

Bagaimana tidak, Objantoro dalam tulisannya mengungkapkan bahwa timbulnya masa pencerahan (Renaissance) di Eropa pada abad ke-15, telah memaklumkan bahwa manusia sendiri adalah kaidah segala sesuatu yang ada, bukan Gereja atau Alkitab. Ini menimbulkan sebuah ideology baru yakni Sekularisme, yang menekankan sisi rasionalisme atau menekankan pada kemampuan intelektual manusia. Dari ideology inilah sehingga muncul paham-paham yang lain seperti liberalisme, materialisme, dan sebagainya. ${ }^{3}$

Kondisi ini bertambah parah dengan kemerosotan moral dan spiritual yang terjadi di gereja dan masyarakat pada waktu itu. Chandra Wim yang mengutip Chad Owen Brand dalam tulisannya mengungkapkan bahwa: "mabuk oleh minuman keras telah menjadi rutinitas sehari-hari. Kriminalitas semakin menjadi-jadi. Pencuri roti yang ditangkap dan dihukum gantung menjadi tontonan yang rutin. Sebuah lembaga survey menyimpulkan bahwa $90 \%$ dari mempelai wanita yang menikah telah hamil di luar nikah. Pada sisi yang lain, di kebanyakan gereja waktu itu, legalisme, dan bukannya Injil Kristus, telah menjadi pusat dari kehidupan bergerja." 4

Itulah sebabnya salah satu gerakan yang memicu terjadinya kebangkitan rohani adalah Golongan Pietis. Pietis adalah gerakan kebangunan rohani yang terjadi pada tahun 1648. Golongan ini didirikan oleh Philip Jakob Spener (1635-1705 M) yang juga disebut sebagai "bapak Pietis". Ia adalah seorang teolog Jerman, yang dengan tegas mengatakan bahwa umat Kristen harus memiliki pengalaman dilahirkan baru dan harus mempunyai hati misi. ${ }^{5}$ Golongan inilah yang sangat memengaruhi terjadinya kebangkitan rohani di Eropa.

${ }^{1}$ Christopher J. Wright, Misi Umat Allah: Sebuah Teologi Biblika Tentang Misi Gereja (Jawa Timur: Literatur Perkantas, 2013), 366.

${ }^{2}$ David J. Bosch, Transformasi Misi Kristen: Sejarah Teologi Misi yang Mengubah dan Berubah (Jakarta: Gunung Mulia, 1997), 426-427.

${ }^{3}$ Enggar Objantoro, "Sejarah dan Pemikiran Kaum Injii Di Tengah-Tengah Perubahan Dan Tantangan Zaman," Evangelikal: Jurnal Teologi Injili dan Pembinaan Warga Jemaat1, No. 2 (Juli 2017):133.

${ }^{4}$ Chandra Wim, "The Chronicles of Evangelism: Sebuah Pengantar Historis terhadap Gerakan Evangelikal," Veritas 12, No. 2 (Oktober 2011):197. Wim mengutip Chad Owen Brad, "Defining Evangelicalism" dalam Reclaming the Center, 285-286.

5Paulus Daun, Misiologi dalam Perspektif Historikal\& Doktrinal (Jakarta: Serving in Mission, 2015), 125. 
Bukan hanya itu saja. Ada juga suatu gerakan yang cukup mengambil andil dalam memengaruhi terjadinya kebangitan rohani. Kaum Puritan Inggris yang sangat dipengaruhi oleh Calvin, menginginkan reformasi lanjutan terjadi dalam gereja Inggris. Puritanisme berkembang di Inggris di sekitar abad ke-17 sebagai sebuah gerakan pembaruan dan kebangunan di dalam gereja resmi Inggris (Church of England). ${ }^{6}$ Inilah yang melatarbelakangi terjadinya kebangkitan rohani.

Dalam bukunya, Bosch mengatakan bahwa "para ahli sejarah membedakan antara Kebangkitan Besar (Great Awakening), suaturangkaian revival (kebangkitan kembali) di kolonial Amerika antara 1726-1760, dan suatu gerakan kedua, yang berlangsung kira-kira antara 1787-1825, dan yang di Inggris disebut Kebangkitan Evangelikal (Evangelical Revival). Namun, di Amerika Serikat, gerakan ini dikenal sebagai Kebangkitan Besar Kedua (Second Great Awakening). Masing-masing dari kedua gerakan ini melahirkan pengaruh yang mendalam terhadap misi." 7

Untuk itulah, kebangkitan rohani atau revivals eyogianya memiliki hubungan dengan misi begitupun sebaliknya. Melalui tulisan ini, penulis akan menjelaskan mengapa sampai keduanya berhubungan, memaparkan beberapa kebangkitanrohani yang terjadi dan bagaimana hati misiikut di dalamnya? Tujuannya untuk menjelaskan hubungan antara misi dan kebangkitan rohani ditinjau dari penjelasan Alkitab, dan sejarah misi dan sejarah kebangkitan rohani.

\section{Metode}

Metode yang digunakan adalah penelitian kualitatif deskripstif dengan menggunakan kajian kepustakaan yang diambil dari rujukan buku-buku, jurnal, artikel online di mana hasilnya dibahas dengan penjelasan yang sistematis yaitu definisi misi, dan kebangunan rohani. Penjelasan ini dilanjutkan dengan landasan alkitabiah, dan kesejarahan kebangunan rohani yang pernah terjadi dengan melibatkan tokoh-tokoh sejarah kebangunan rohani dan filosofis hidup mereka yang berkaitan dengan misi Amanat Agung Yesus Kristus.

Penulis melakukan observasi terhadap rujukan dari berbagai sumber, dan mereduksi data-data yang diperoleh, dan memilah selanjutnya dijelaskan dan disimpulkan ${ }^{8}$

\section{Hasil dan Pembahasan}

\section{DefinisiMisi dan KebangkitanRohani}

Sebelum penulis memaparkan definisi misi dan kebangkitan rohani agar dapat dipahami apa sebenarnya yang dimaksud dengan misi, dan kebangkitan rohani.

Misi

Istilah misi berasal dari beberapa penggunaan kata dalam bahasa Yunani, Latin, Inggris. Dalam bahasa Latin "misisio" yang diangkat dari kata dasar "mittere" yang berkaitan dengan kata "missum" yang artinya to send atau dalam bahasa Indonesia dapat

${ }^{6}$ Wim, 196.

7Bosch, 427-428.

${ }^{8}$ Hengki Wijaya, Analisis Data Kualitatif Ilmu Pendidikan Teologi (Makassar: Sekolah Tinggi Theologia Jaffray, 2018), 55-59; Matthew B. Miles, A. Michael Huberman, QualitativeData Alanysis: A Sourcebook of New Methods (London: SAGE Publications, 1984). 
diartikan mengirim atau mengutus. ${ }^{9}$ Dalam bahasa Yunani "apostello" yang berarti mengirim dengan otoritas. ${ }^{10}$

Kata misi dalam bahasa Inggris yakni mission dan missions secara esensi. Mission berarti pekerjaan-pekerjaan spesifik yang dilakukan gereja dan lembaga gerejawi dalam melaksanakan tugas penjangkauan orang-orang bagi Kristus melalui pelayanan lintas budaya. Sedangkan missions lebih luas, menunjukkan kepada segala sesuatu yang gereja lakukan yang mengarah kepada kerajaan Allah.

Menurut Van Egen, misi adalah umat Tuhan secara intensif melakukan pekerjaan melintas dari gereja keluar gereja, dari iman kepada orang yang tidak beriman melalui perkataan dan perbuatan untuk memproklamasikan kerajaan Allah di dalam Yesus Kristus. ${ }^{11}$ Peter Wongso melanjutkan bahwa gereja sebagai mandataris Allah yang telah menerima Amanat Agung memiliki tanggung jawab untu kmemberitakan Injil kepada setiap orang yang belum selamat. Gereja adalah pengemban tugas menyampaikan Amanat Agung itu. Gereja diutus sebagai suatu subjek yang wajib membagikan keselamatan yang telah diterimanya kepada dunia ini sebagai objek dari misi Allah tersebut. Dunia ini yang adalah objek dari misi gereja berisi masyarakat luas dengan berbagai macam ragam perbedaan dan kemajemukan didalamnya dan gerejatidakbisadipisahkan darihal-hal tersebut. ${ }^{12}$

Misi adalah suatu upaya yang melibatkan setiap orang percaya secara aktif dalam hal pengembangan Kerajaan Allah di muka bumi ini (Matius 28).

\section{Kebangkitan Rohani}

Kebangkitan rohani atau kebangunan rohani merupakan istilah yang sering dikenal dalam kekristenan dengan ditandai oleh hidupnya kembali gairah kerohanian yang kandas. Revival adalah arti dalam bahasa Inggrisnya. Istilah ini adalah sebuah tanda bahwa tangan Tuhan sedang menjamah, mengurapi dan berkarya di sebuah tempat yang ditandai dengan berkobarnya api penginjilan. Itulah sebabnya, kebangkitan rohani adalah suatu hal yang penting dan perlu dirasakan oleh setiap gereja Tuhan agar penuaian jiwa besar-besaran dapat terjadi,semuanya tentu untuk kemuliaan namaTuhan semata.

Hotben Lingga dalam tulisannya, menyatakan bahwa:

Revivalisme (Kebangunan Rohani) atau Great Awakening (Kebangunan Rohani Besar) merupakan istilah yang biasanya menunjuk pada suatu periode/zaman tertentu dimana minat dan antusiasme terhadap hal-hal rohani meningkat dan terjadi gelombang pembaharuan rohani dalam kehidupan jemaat gereja baik secara lokal maupun global. Revivalisme menunjuk pada periode kebangkitan agama dalam sejarah keagamaan bangsa Amerika. Dalam sejarah gereja, Revivalisme adalah fenomena khas Protestan, khususnya Protestantisme di Amerika Utara dan Eropa. Dimana pengkhotbah-pengkhotbah (pendeta) "terbang" mendesak para pendengarnya untuk menerima pengampunan atas dosa-dosa pribadi mereka melalui

${ }^{9}$ Rick Warren, The Purpose Driven Life (Surabaya: Gandum Mas, 2007), 309.

${ }^{10}$ Edmund Woga, Dasar-Dasar Misiologi (Yogyakarta: Kanisius, 2002), 14.

11“Diktat Misiologi”, diakses 08 Januari 2019, http://stt-oi.ac.id/akademik-163-diktatmisiologi.html

${ }^{12}$ Peter Wongso, Tugas Gereja Dan Misi Masa Kini (Malang: Seminari Alkitab Asia Tenggara, 1996), 129. 
iman di dalam Yesus Kristus dan berkomitmen untuk hidup kudus/suci, rajin membaca Alkitab dan gereja. ${ }^{13}$

Selain itu, Duncan Campbell, seorang Penginjil Skotlandia yang terkenal karena menjadi pemimpin dalam Kebangkitan Lewis atau Kebangkitan Hebrides, kebangkitan rohani abad pertengahan ke-20 di Hebrides Skotlandia, mengakatan bahwa "kebangunan rohani adalah sebuah komunitas yang dipenuhi oleh Allah. Itulah perbedaan antara kebangunan rohani dan penginjilan. Dalam penginjilan yang berhasil, dalam kebaktian kebangunan rohani yang berhasil, Anda mendapatkan sepuluh orang, Anda mendapatkan dua puluh orang diselamatkan di sini, Anda mendapatkan seratus orang yang dibawa kepada Kristus di sana, tetapi masyarakat tetap tidak berubah."14

Selanjutnya Charles Finney, salah seorang dari pemimpin Kebangkitan Besar Kedua (Second Great Awakening) menjelaskan pengertiannya mengenai kebangkitan rohani sebagai berikut.

I said that a revival is the result of the right use of the appropriate means. The means which God has enjoined for the production of a revival, doubtless have a natural tendency to produce a revival. In the Bible, the Word of God is compared to grain, and preaching is compared to sowing the seed, and the results to the springing up and growth of the crop. A revival is as naturally a result of the use of the appropriate means as a crop is of the use of its appropriate means. ${ }^{15}$

(Terjemahan: Saya mengatakan bahwa kebangunan rohani adalah hasil dari penggunaan yang benar dari sarana yang tepat. Cara-cara yang diperintahkan Allah untuk menghasilkan kebanguan rohani, tidak diragukan memiliki kecenderungan alami untuk menghasilkan kebangunan rohani. Dalam Alkitab, Firman Tuhan dibandingkan dengan biji-bijian, dan khotbah dibandingkan dengan menabur benih, dan hasilnya adalah berseminya dan bertumbuhnya tanaman. Kebangunan rohani secara alami adalah hasil dari penggunaan cara yang tepat seperti halnya panen adalah penggunaan cara yang tepat).

Berdasarkan beberapapengertian di atas penulis mengambil kesimpulan bahwa kebangunan rohani adalah kegerakan iman yang hanya terjadi atas kedaulatan Allah atas umat-Nya melalui campur tangan Roh Kudus dengan ditandai pemberitaan Injil Kristus. Dengan kata lain, kebangkitan rohani hanya terjadi atas kehendak Allah Tritunggal yang kudus. Manusia hanya sebagai saluran atau perpanjangan tangan Tuhan dalam mempelopori terjadinya kebangkitan rohani. Itu sebabnya misi dan kebangkitan rohani merupakan dua hal yang tidak dapat dipisahkan. Sebab Allah pembuat kebangkitan rohani melakukan kegerakan rohani dalam diri para misionaris sehingga mereka dengan semangat yang berkobar dapat melakukan misi sehingga terjadilah apa yang dinamakan kebangkitan rohani. Ini ditandai dengan hidupnya kembali spiritualitas orang percaya. Maka dari itu,

${ }^{13}$ Hotben Lingga, "Sekilas Tentang Revivalisme (Gerakan Kebangunan Rohani) Protestan," diakses 08 Januari 2019, http://suarakristen.com/2015/03/02/sekilas-tentang-revivalisme-gerakankebangunan-rohani-protestan/

${ }^{14 “}$ "Definisi Kebangunan Rohani," diakses 08 Januari 2019,

http://google.com/amp/s/hanya1percikan.wordpress.com/2014/09/22/definisi-kebangunanrohani/amp/?espv=1

${ }^{15}$ Charles Finney, "Revival Lectures," diakses 08 Januari 2019, http://www.whatsaiththescripture.com/Voice/Revival.Lectures.html 
dampak kebangunan rohani harus dirasakan keluar dari gereja karena kalau tidak itu tidak dapat dikatakan kebangunan rohani.

\section{Landasan Alkitab Mengenai Misi dan Kebangkitan Rohani Perjanjian Lama}

Ada begitu banyak kisah dalam Perjanjian Lama yang menceritakan bagaimana kebangkitan rohani terjadi dan melingkupi umat pilihan Tuhan. Mungkin sebagian akan menjelaskan kebangkitan rohani yang terjadi pada masa perbudakan di Mesir pada masa pembuangan di Babel. Namun ada satu kisah yang menarik perhatian penulis. Kisah ini sangat menggambarkan bahwa ada hubungan yang terjadi antara misi dan kebangkitan rohani. Kisah ini juga dapat menjadi pembelajaran bagi setiap gereja Tuhan bahwa hanya karena kemurahan Tuhanlah sehingga kebangkitan rohani itu dapat terjadi.

Siapa yang tidakkenal dengan Nabi Yunus. Ia adalah seorang nabi yang terkenal dengan pengingkarannya terhadap panggilanTuhan. Namun siapa sangka, dalam Yunus 3, firman Tuhan kembali datang kepadanya untuk kedua kalinya demikian: "Bangunlah, pergilah ke Niniwe, kota yang besar itu, dan sampaikanlah kepadanya seruan yang Kufirmankan kepadamu," (Yun. 3:2).

Browning mengatakan bahwa Niniwe adalah ibu kota kerajaan Asyur, terletak di tepi timur Sungai Tigris, dan pernah menjadi kota paling perkasa di dunia. Tetapi, Niniwe kemudian direbut oleh Babel dan Media pada $612 \mathrm{sM}$. Akhir kebesaran kota Niniwe telah dinantikan oleh Zefanya (Zef. 2:13-15) dan Nahum, yang seluruh kitabnya ditujukan melawan 'kota penumpah darah' (Neh. 3:1), yang akan dilumat habis, seperti dihancurkan oleh belalang (Neh. 3:15). Nabi Yunus diceritakan pernah berkhotbah di Niniwe (Yun. 3:3; Luk. 11:30).16

Kota yang terkenal dengan "kota penumpah darah" itu bahkan Allah sendiripun mengakui bahwa "kota yang berpenduduk lebih dari seratus dua puluh ribu orang, yang semuanya tak tahu membedakan tangan kanan dari tangan kirinya" dapat diubah seketika melalui revival atau kebangkitan rohani melalui seorang nabi yang dikatakan "pembangkang" tersebut. Namun di sinilah dapat diketahui bahwa atas kedaulatan Tuhanlah kebangkitan rohani itu dapatterjadi.

Hanya dengan sebuah kalimat yang diucapkan oleh Yunus: "Empat puluh hari lagi, maka Niniwe akan ditunggangbalikkan," seluruh penduduk Niniwe percaya kepada Allah, lalu mengumumkan puasa, baik orang dewasa, maupun anak-anak bahkan sampai lembu sapi dan kambing domba-pun tidak diperbolehkan makan apa-apa. Seluruh penduduk berselubung kain kabung dan mereka berseru dengan suara yang keras kepada Allah meminta pengampunan. Dari peristiwa inilah sehingga Allah menyesal dan tidak jadi menimpakan malapetaka yang telah dirancangkan-Nya kepada mereka.

Oleh sebab itu, melalui pertobatan besar-besaran yang dialami oleh bangsa Niniwe menunjukkan kebangkitan rohani terjadi bagi mereka. Hal ini kembali menunjukkan kepada gereja Tuhan bahwa hanya Allah yang berdaulat atas kebangkitan rohani yang terjadi sehingga manusia tergerak hatinya untuk terlibat dalam pelayanan misi (Yunus 3:5-9). Itulah sebabnya gereja Tuhan perlu meresponi panggilan Tuhan yang sudah ditugaskan kepadanya.

\section{Perjanjian Baru}

Kebangkitan Rohani terbesar yang tercatat dalam Perjanjian Baru adalah saat hari Pentakosta. Dokter Lukas dalam sekuelnya mencatat bahwa: "saat orang percaya berkumpul

${ }^{16}$ W.R.F. Browning, Kamus Alkitab (Jakarta: BPK Gunung Mulia, 2007), 291 
di satu tempat, tiba-tiba turunlah dari langit suatu bunyi seperti tiupan angin keras yang memenuhi seluruh rumah, di mana mereka duduk; dan tampaklah kepada mereka lidahlidah seperti nyala api yang bertebaran dan hinggap pada mereka masing-masing. Maka penuhlah mereka dengan Roh Kudus, lalu mereka mulai berkata-kata dalam bahasa-bahasa lain, seperti yang diberikan oleh Roh itu kepada mereka untuk mengatakannya." (Kisah Para Rasul 2:1-4).

Dari kebangkitan rohani tersebutlah sehingga menggerakkan hati Petrus untuk berani menyampaikan khotbahnya kepada orang Yahudi dan semua orang yang tinggal di Yerusalem demikian: "Bertobatlah dan hendaklah kamu masing-masing member dirimu dibaptis dalam nama Yesus Kristus untuk pengampunan dosamu, maka kamu akan menerima karunia Roh Kudus. Sebab bagi kamulah janji itu dan bagi anak-anakmu dan bagi orang yang masih jauh, yaitu sebanyak yang akan dipanggil oleh Tuhan Allah kita." (Kisah Para Rasul 2:38-39).

Setelah Petrus menyampaikan khotbahnya, orang-orang yang mendengarnya pun member diri dibaptis dan pada hari itu jumlah mereka kira-kiratiga ribu jiwa (Kisah Para Rasul 2:41) bahkan tidak selang beberapa lama, jumlah mereka bertambah menjadi kira-kira lima ribu orang laki-laki (Kisah Para Rasul 4:4). Orang-orang inilah yang kemudian disebut sebagai jemaat Kristen yang pertama. Mereka hidup sehati dan sejiwa. Banyak tanda dan mujizat yang dilakukan oleh para rasul. Mereka bertekun dalam doa dan pengajaranpengajaran Alkitab. Sehingga pada akhirnya, ketika terjadi penganiayaan, mereka bukannya bersembunyi namun mereka menjelajah seluruh negeri itu sambil memberitakan Injil (Kisah Para Rasul 8:4).

Melalui hal tersebut, dapat diketahui bahwa kebangkitan rohani hanya terjadi melalui pencurahan Roh Kudus yang dikerjakan tentu oleh Allah sendiri. Hal tersebut yang pada akhirnya memberanikan umat Tuhan untuk pergi melakukan pelayanan misi dengan memberitakan Injil keseluruh negeri walaupun penganiayaan besar-besaran sedang terjadi. Itulah mengapa, kembali penulis sampaikan bahwa ada keterkaitan antara pelayanan misi dan kebangkitan rohani. Saat kebangkitan rohani terjadi, gereja Tuhan walaupun dalam keadaan terdesak sekalipun justru membuat roh mereka semakin menyala-nyala untuk memberitakan Injil keselamatan.

\section{Beberapa Kebangkitan Rohani yang Terjadi}

Kebangkitan Besar (Great Awakening)

Kebangkitan rohani yang pertama dikenal dengan Kebangkitan Besar (Great Awakening) yang terjadi di Amerika Serikat (1726-1760 M). Kebangkitan Besar dimulai dalam jemaat-jemaat Hervormd Belanda di Lembah Ratiran di New Jersey. Dari sana gerakan ini menyebar ke denominasi-denominasi lainnya, terutama sepanjang pantai Atlantik. Dari daerah inilah sehingga muncul seorang yang bernama Jonathan Edwards. Ia merupakan seorang Presbiterian dan menjadi pelopor dari kebangkitan rohani ini. ${ }^{17}$

Selanjutnya Bosch mengutip perkataan Niebuhr bahwa bagi Amerika, Kebangkitan Besar adalah satu permulaan baru, "ini adalah pertobatan nasional kami." Terutama melalui Edwards-lah sehingga kebangkitan ini berhasil menahan gelombang Rasionalisme yang dangkal, mematahkan belenggu-belenggu dari Puritanisme yang beku dan dengan demikian memulihkan dinamika bagi gereja Tuhan. ${ }^{18}$

Maka dari itu tak dapat disangkal jika Edwards paling dikenal sebagai teolog besar Amerika Utara yang pertama. Ia juga dikenal sebagai seorang misionaris kepada bangsa-

${ }^{17}$ Bosch, 428.

${ }^{18}$ Ibid. 
bangsa pribumi Amerika di Massachusetts barat. Itulah sebabnya ia mendapatkan sebuah proposal dari teman-temannya di Skotlandia untuk sebuah "KonserDoa" untuk mempersatukan orang-orang Kristen yang prihatin akan kebangkitan gereja pada kedua sisi Samudera Atlantik. Berdasarkan hal tersebut, ia kemudian menerbitkan sebuah pamflet yang berpengaruh dalam mempromosikan spiritualitas misi dan keesaan Kristen. ${ }^{19}$

Pandangan ini juga disetujui oleh pernyataan Paulus Daun yang menyatakan bahwa kegerakan rohani ini dipelopori oleh Jonathan Edwards dan kemudian dilanjutkan oleh George Whitefield. Pada tahun 1740, penduduk di New England yang berjumlah tiga ratus ribu orang menjadi dua puluh lima ribu orang yang bertobat. Hal ini mengingatkan kembali kepada peristiwa yang dialami oleh jemaat mula-mula seperti penjelasan di bagian landasan Alkitab. Pada tahun yang sama, George Whitefield datang dan mengadakan serentetan Kebaktian Kebangunan Rohani sehingga dicatat bahwaadaseratus lima puluh gereja dan banyak rohani awan memperoleh kebangunan. ${ }^{20}$

Tercatat bahwa Whitefield berkhotbah kepada kira-kira delapan ribu orang setiap hari selama sebulan walaupun ia masih terbilang cukup muda, dengan usia 25 tahun. Tujuan utamanya ialah menawarkan kasih karunia Allah kepada umat-Nya yang berdosa.21 Melalui kebangunan ini, membawa dampak bukan saja terjalinnya hubungan antar gereja, namun denominasi dipulihkan, pendidikan tinggi dihargai, bahkan pekerjaan misi sangat diperhatikan.22 Inilah bukti bahwa kebangkitan rohani sangat perlu untuk dialami oleh gereja Tuhan. Sebab melalui kebangkitan rohani, umat Tuhan bukan hanya dipulihkan namun mereka tergerak untuk memerhatikan bahkan melakukan pekerjaan misi.

\section{Kebangkitan Besar Kedua (Second Great Awakening)}

Bosch mengatakan bahwa kebangkitan yang pertama tidak secara langsung melahirkan kegiatan-kegiatan misioner, meskipun gerakan itu yang menjadi dasar peletakannya. Itu sebabnya dalam bukunya, ia mencatat bahwa muncul suatu gerakan kedua, yang berlangsung kira-kira antara 1787-1825 yang disebut di Amerika Serikat sebagai Kebangkitan Besar Kedua (Second Great Awakening). Namun berbeda dengan di Inggris. Gerakan kedua ini disebut sebagai Kebangkitan Evangelikal (Evangelical Revival). ${ }^{23}$

Kebangkitan Besar Kedua ini dipelopori oleh John Wesley bersama adiknya Charles Wesley dan rekannya George Whitefield. Paulus Daun mencatat bahwa:

Sumbangan kebangunan ini sangat besar, di samping dampaknya bukan saja sebagai peloporan Gerakan Injili masa kini, tetapi juga perubahan yang luar biasa di tengahtengah masyarakat; di antaranya terjadi pelarangan penjualan dan pembelian budak, perubahan kesejahteraan bagi kaum buruh, perbaikan rumah tahanan dan sebagainya. Sumbangsih lain yang cukup besar adalah di bidang pendidikan Kristen. Pelayanan di bidang Sekolah Minggu digalakkan, dan pada tahun 1803 berdiri Badan Pelayanan Sekolah Minggu Inggris dan tahun 1824 berdiri juga Badan Pelayanan Sekolah Minggu di Amerika. Gerakan kebangunan rohani ini juga membawa kebangunan bagi gerejagereja Tuhan. Di Gereja Methodis Amerika, sekitar tahun 1800 yang berkunjung

\footnotetext{
${ }^{19}$ Norman E. Thomas, Teks-teks Klasik Tentang Misi Dan Kekristenan Sedunia: Melengkapi Adikarya David Bosch, Transformasi Misi Kristen (Jakarta: Gunung Mulia, 1998), 74.

${ }^{20}$ Daun, 129-130.

${ }^{21}$ Andrew Brake, Diktat Sejarah Misi (Makassar: STT Jaffray Makassar, 2018), 92. Belum dipublikasikan.

${ }^{22}$ Daun, 130.

${ }^{23}$ Bosch, 428-429.
} 
kurang dari tiga ribu orang, tetapi kemudian pada tahun 1830 sudah bertambah sampai seratus tujuh puluh ribu orang dan banyak Sekolah Teologi Injili didirikan. ${ }^{24}$

Pandangan ini sejajar dengan pendapat Bosch yang menyatakan bahwa gereja Metodis, Baptis dan Presbiterian mulai mengalami pertumbuhan yang berarti pada awal Revolusi Amerika. Hal ini dibuktikan pada tahun 1800 persentase keanggotaan gereja hamper dua kali lipat. Itu sebabnya pada tahun 1817 usaha missioner telah menjadi semangat besar gereja-gereja Amerika. ${ }^{25}$ Bahkan salah satu produk yang paling menonjol dari Kebangkitan Injili, baik di Inggris maupun di Amerika Utara (dan malah juga di daratan Eropa dan koloni-koloni Inggris) adalah pembentukan perhimpunan-perhimpunan yang secara khusus dimaksudkan untuk misi luar negeri. Mereka yang disentuh oleh revival tidak lagi rela untuk tinggal diam dan menunggu gereja-gereja resmi untuk mengambil inisiatif. Sebaliknya, orang-orang Kristen secara pribadi, berkumpul bersama demi misi dunia. ${ }^{26}$

Berdasarkan pandangan hal tersebut, kembali kita diingatkan akan kebangkitan rohani yang dialami oleh jemaat mula-mula, di mana mereka tidak tinggal diam dalam memberitakan Injil sekalipun terjadi penganiayaan (Kisah Para Rasul 8:4). Inilah yang menjadi tanda terjadinya kebangkitan rohani yaitu sebuah kondisi di mana gereja Tuhan dengan semangat yang berkobar-kobar menyampaikan Injil keselamatan kepada jiwa-jiwa yang terhilang.

\section{Gerakan Misi Modern}

Rupanya Kebangkitan Besar Kedua (Second Great Awakening) membawa dampak pula bagi pekerjaan misi. Gerakan ini dikenal dengan nama "Gerakan Misi Modern." Pelopor dari gerakan ini adalah William Carey yang juga dikenal sebagai "Bapak Misi Modern." Namun menurut Justice Anderson, Carey lebih tepat disebut sebagai "father of modern missionary movement" (Bapak GerakanMisi Modern) sebab misi yang dilakukan Gereja Anglikan, Moravian adalah pendiri-pendiri misi lintas budaya namun Carey adalah orang yang melahirkan gerakan misi. ${ }^{27}$

Selanjutnya William Carey disebut berjasa sebagai bapak misi modern bukan karena apa yang telah dikerjakannya di India tetapi oleh karena tulisan dan dorongannya, akhirnya lahirlah puluhan lembaga misi yang siap mengutus para misionaris dan mendorong munculnya ratusan penginjil yang siap diutus dan bertepatan dengan saat itu juga, menjadi gerakan mobilisasi terbesar sepanjang sejara gereja Protestan. Dalam bukunya, Daniel Ronda mencatat bahwa Carey lahir di Inggris pada tanggal 17 Agustus 1761. Walaupun ia terlahir dalam keluarga yang miskin di sebuah desa yang terpencil, namun dia berhasil melewati proses persiapan dan pendidikan sehingga pada akhirnya Carey dilantik menjadi gembala di sebuah Gereja Baptis yang kecil.28

Ada sebuah khotbahnya yang sangat terkenal yakni "Expect Great Things from God, Attempt Great Things for God (Harapkanlah Hal-hal Besardari Allah, Usahakanlah Hal-hal Besar bagi Allah). Sebelum ia menyampaikan khotbahnya ini, ia menerbitkan pamfletnya yang berjudul "An Enquiry into the Obligation of Christian to Use Means for the Conversation of Heathens" (Orang Kristen Mempunyai Kewajiban Membawa Orang

${ }^{24}$ Daun, 130-131.

${ }^{25}$ Bosch, 431.

26Ibid., 433.

27Daun, 131. Daun mengutip John Mark Terry, dkk,. Missiology: Makalah Justice Anderson pen. Chen-Khoo maw Ling dkk. (Kowloon, Hong Kong: Chinese Baptist Press Limited, 2010), 239.

${ }^{28}$ Daniel Ronda, Kisah-kisah Misi Singkat Di Berbagai Belahan Dunia (Makassar: STT Jaffray Makassar, 2018), 28. 
Beragama Lain untuk Percaya) yang berjumlah 87 halaman namun tidak begitu laku. Namun setelah ia menyampaikan khotbahnya tersebut, kurang dari lima bulan kemudian, Perhimpunan Misionaris Baptis (Baptist Missionary Society) terbentuk. Selanjutnya berturutturut diikuti dengan terbentuknya Perhimpunan Misionaris London (London Missionary Society), Perhimpunan Misi Gereja (Church Mission Society), Perhimpunan Traktat Keagamaan (Religious Tract Society), Lembaga Akitab Inggris dan Luar Negeri (British and Foreign Bible Society), dan lain-lainnya. Pada akhirnya, Carey berangkat ke India dan keteladannya mengilhami begitu banyak orang sehingga ia dikenal sebagai Bapak Misi Protestan. ${ }^{29}$

Berdasarkan hal tersebut, dapat diketahui bahwa ketika firman Allah sungguhsungguh disampaikan maka tidak menutup kemungkinan bahwa kebangkitan rohani dapat terjadi. Hal ini kembali mengingatkan atas peristiwa yang dialami oleh nabi Yunus. Ketika ia menyampaikan firman Allah, maka kebangkitan rohani terjadi bagi Niniwe. Begitu pula yang dialami oleh William Carey. Melalui khotbah yang ia sampaikan, begitu banyak lembaga misi terbentuk dan pada akhirnya mereka berani untuk melakukan pelayanan misi hingga keluar negeri.

\title{
Hubungan Misi dan KebangkitanRohani
}

Kebangkitan Rohani Membangkitkan Semangat Bermisi

Berdasarkan beberapa contoh kebangkitan rohani yang sudah dipaparkan oleh penulis di atas, hubungan antara misi dan kebangkitan rohani yang pertama ialah kebangkitan rohani membangkitkan semangat bermisi. Hal ini ditandai dengan begitu banyaknya misionaris yang terjun dalam pelayanan misi. Bukan hanya sampai di situ saja, bahkan gerakan-gerakan misi mulai dibentuk dan dapat dirasakan dampaknya hingga beberapa tahun setelahnya. Misalnya saja pelayanan Jonathan Edwards dalam Kebangkitan Besar (Great Awakening). Pelayanan Edwards rupanya sangat berpengaruh terhadap kehidupan David Brainerd yang tidak lain adalah teman sekaligus calon anak mantunya.

Dalam buku harian Brainerd, di dalamnya terdapat laporan tentang perjalanan, pekerjaan dan meditasinya pada tahun 1974. Di situ Brainerd mengungkapkan bahwa kebangkitan rohani membangkitkan dan mengobarkan semangatnya dalam bermisi demi kemuliaan Allah dan keselamatan semua orang. Thomas mencatat bahwa selama lebih dari satu abad, Buku Hariannya itu menjadi klasik di antara orang-orang Protestan di Atlantik Utara dan sangat dalam mempengaruhi John Wesley, William Carey, Henry Martyn dan para misionaris lainnya. ${ }^{30}$

Begitu pula sebaliknya yang terjadi dalam kehidupan John Wesley, William Carey dan Henry Martyn. Ketiganya sangat berpengaruh terhadap generasi selanjutnya. Pertama, John Wesley misalnya, dari pelayanannya dengan beberapa mahasiswa yang membuka persekutuan doa, sehinggaTuhan menanamkan kepada mereka hati untuk memberitakan Injil di antara orang Indian di Amerika. Inilah yang mempelopori gerakan metodis, yang sekarang tersebar di seluruh dunia. ${ }^{31}$

Kedua, William Carey, dia terbeban dengan kebutuhan rohani dari suku-suku bangsa yang belum pernah mendengar Injil. Dengan mengalami begitu banyak tantangan, termasuk dari istrinya yang menentangnya, ia pada akhirnya pergi ke India di bawah Lembaga Misi Baptis. Semua ini dipengaruhi oleh doa dari kelima temannya yang berjanji untuk

\author{
${ }^{29}$ Thomas, 80-81. \\ 30Thomas, 77-78. \\ 31Veronika J. Elbers, Doa dan Misi (Malang: Literatur SAAT, 2010), 17.
}


mendukung Carey dalam doa seumur hidup mereka. Itulah sebabnya Carey pergi ke India dan membawa Injil kesana. Sesudah itu ia menerjemahkan Alkitab kedalam 35 bahasa. ${ }^{32}$

Di samping William Carey, Henry Martyn adalah juga seorang misionaris yang juga dipengaruhi oleh "Evangelical Revival" (Kebangunan Injili), sehingga pada tahun 1806, ia pergi ke Kalkuta, India dan terlibat langsung dengan pekerjaan misi dan berhasil menerjemahkan Alkitab Perjanjian Baru kedalam bahasa Urdu, Persia dan Arabiah. ${ }^{33}$ Henry Martyn dipengaruhi oleh David Brainerd bahkan ia mengikut cara berdoa Brainerd yang lama setiap harinya. ${ }^{34}$ Berdasarkan hal tersebut, penulis menyimpulkan bahwa kebangkitan rohani sangat berhubungan erat dengan misi khususnya dalam membangkitkan semangat bermisi bagi pelayanan para misionaris.

\section{Doa Bagi Pelayanan Misi Kunci Terjadinya Kebangkitan Rohani}

Hubungan yang kedua antara misi dan kebangkitan rohani adalah doa-doa yang dinaikkan bagi pelayanan misi. Inilah yang merupakan salah satu kunci terjadinya kebangkitan rohani. Contoh konkret yang dapat dilihat dari terjadinya kebangkitan rohani adalah dari doa-doa yang dinaikkan oleh para hambaTuhan bagi pelayanan misi. Veronika Elbers mencatat dalam bukunya bahwa Martin Luther, sang bapak reformator, berkata: "Jika saya gagal untuk berdoa setiap dua jam sehari setiap pagi, maka iblis mendapat kemenangan sepanjang hari. Saya mempunyai banyak sekali pekerjaan sehingga saya tidak dapat memulainya sebelum mengasingkan waktu tiga jam dalam doa setiap hari." Selain itu, ada juga kisah lain yang dicatatnya bahwa: "pada waktu lima orang siswa SMU bertemu di Kota Halle di Jerman untuk berdoa dan membaca firman Tuhan bersama-sama, persekutuan ini menjadi benih bagi gerakan misi Moravia yang begitu penting dalam sejarah gereja." 35

Kemudian pada bulan Oktober 1744 sejumlah pendeta di Skotlandia sambil mempertimbangkan keadaan gereja Tuhan dan dunia, mereka digerakkan oleh Tuhan untuk sungguh-sungguh menaikkan doa kepada-Nya agar Ia muncul dalam kemuliaan-Nya, dan menunjukkan belas kasih-Nya kepada gereja dan dunia, untuk menghidupkan kembali agama sejati di seluruh bagian dunia Kristen dan membebaskan segala bangsa dari bencana dan penderitaan rohani yang besar dan memberkati mereka dengan berkat-berkat sehingga seluruh bumi penuh dengan kemuliaan-Nya. Melalui doa yang mereka naikkan ini, Roh Kudus menggerakkan hati mereka untuk terus menaikkan doa-doa mereka dan bukan sampai di situ saja, mereka juga membujuk orang-orang lain melakukan hal yang sama. Itu sebabnya pada tahun 1792, Edwards mengilhami William Carey dan para pemimpin dari perhimpunan misi yang pertama di Amerika Serikat untuk mencantumkan dalam usaha misi mereka, doa-doa yang sungguh-sungguh demi perluasan Kerajaan Allah. ${ }^{36}$

Perlu juga dicatat bahwa buku Jonathan Edwards yang membahas mengenai doa yang berjudul "An Humble Attempt to Promote an Explicit Agreement and Visible Union of God's People, in Extraordinary Prayer for the Revival of Religion, and the Advancement of Christ's Kingdom in the Earth (Suatu Upaya Rendah Hati untuk Mengemukakan Kesepakatan yang Jelas dan Tampak dari Umat Allah, dalam Doa yang Luar Biasa demi Kebangkitan Agama, dan Perluasan Kerajaan Kristus di Muka Bumi), baru diperhatikan lebih dari empat puluh tahun sejak penerbitannya yang pertama pada 1748, dan menjadi pendorong misi dalam berbagai denominasi pada kedua sisi Samudra Atlantik. ${ }^{37}$

\footnotetext{
${ }^{32}$ Ibid.

${ }^{33}$ Daun, 133.

${ }^{34}$ Brake, 101.

${ }^{35}$ Elbers, 16.

36Thomas, 74-75.

37Bosch, 432.
} 
Itulah sebabnya David Bryant mengatakan bahwa: "Doa merupakan satu-satunya misi bagi dunia yang dapat dilakukan oleh semua umat Kristen. Melalui doa, setiap kita secara langsung mengasihi orang-orang yang belum terjangkau Injil, bahkan hingga ke ujung bumi sekalipun. Sejauh Allah mampu menjangkau, demikian pula doa itu." 38 Begitu juga yang diungkapkan oleh S. D. Gordon: "Pekerjaan terbesar yang ditaruh dalam tangan manusia adalah berdoa." 39 Berdasarkan beberapa pengertian tersebut dapat disimpulkan bahwa doa adalah cara terbesar yang dipilih Allah untuk melibatkan kita dalam tindakanNya. Maka dari itu jika seseorang rindu melihat kebangkitan rohani terjadi, cara yang paling tepat ialah berdoa bagi pekerjaan misi. Sebab firman Tuhan berbunyi: "Marilah kita pergi untuk melunakkan hati TUHAN dan mencari TUHAN semesta alam! Kamipun akan pergi! Jadi banyak bangsa dan suku-suku bangsa yang kuat akan datang mencari TUHAN semesta alam di Yerusalem dan melunakkan hati TUHAN." (Zakharia 8:21-22).

\section{Khotbah Dalam Kebangkitan Rohani Mendorong Terjadinya Pelayanan Misi}

Selain doa, khotbah dalam kebangkitan rohani turut memotivasi terjadinya suatu pelayanan misi. Bahkan khotbah-khotbah yang disampaikan pada saat kebangkitan rohani terjadi, sebenarnya merupakan bagian dari pelayanan misi. Itu sebabnya penulis memasukkan poin ini dalam hubungan antara misi dan kebangkitan rohani. Pada umumnya, setiap kali seseorang memikirkan pengorbanan Yesus Kristus, suatu kebangkitan rohani terjadi. Setelah itu, diikuti oleh suatu gerakan misi. ${ }^{40}$ Untuk itu, jika menyelidiki khotbah-khotbah yang disampaikan oleh para misionaris pada saat kebangkitan rohani terjadi, tak lama kemudian setelah itu diikuti oleh terjadinya pelayanan misi.

Salah satu contoh ialah khotbah terkenal dari Jonathan Edwards, yang mengambil andil terjadinya Kebangkitan Besar (Great Awakening) pada 1741. Dengan khotbahnya yang terkenal "Sinners in the Hands of an Angry God" (Orang berdosa di dalam tangan Allah yang murka) dapat mendorong terjadinya pertobatan besar-besaran dan pelayanan misi terbuka bagi orang asli di Massachusetts dari 1751-1757.41 Itu sebabnya Paulus dalam suratnya kepada jemaat di Roma menulis: "Sebab aku mempunyai keyakinan yang kokoh dalam Injil, karena Injil adalah kekuatan Allah yang menyelamatkan setiap orang yang percaya, pertama-tama orang Yahudi, tetapi juga orang Yunani." (Roma 1:16). Maksudnya ialah berita Injil adalah kekuatan Allah yang dapat menyebabkan terjadinya kebangkitan rohani. Untuk itu, berita Injil harus terus disampaikan sebab hanya Allah yang dapat menyelamatkan setiap orang melalui kekuatan kuasa-Nya sehingga pelayanan misi boleh terjadi.

Selain khotbah dari Jonathan Edwards, William Carey juga mempunyai sebuah khotbah yang terkenal yakni "Expect Great Things from God, Attempt Great Things For God (Harapkanlah Hal-hal Besar dari Allah, Usahakanlah Hal-hal Besar bagi Allah). Dampak dari khotbahnya inilah sehingga berdirilah suatu gerakan misi "Baptist Missionary Society" pada tahun 1792. Pelayanan misi ini dapat dikatakan sebagai Badan Misi yang pertama yang didirikan dari hasil Kebangkitan Besar Kedua (Second Great Awakening) atau Kebangkitan Evangelikal (Evangelical Revival). Pelayanan misi ini jugalah merupakan badan misi yang pertama yang mengutus misionaris keluar negeri dan misionaris yang petama diutus adalah William Carey. ${ }^{42}$ Selanjutnya berturut-turut diikuti dengan terbentuknya beberapa gerakan

\footnotetext{
38David Shibley, Pembaruan Karismatik dan Pekabaran Injil Sedunia (Yogyakarta: Andi, 1993$), 87$. 39Ibid., 96.

${ }^{40}$ Brake, 95.

41Ibid., 91.

42Daun, 132.
} 
misi yang juga turut mengambil bagian dalam pelayanan misi yang mengirimkan begitu banyak misionaris keberbagai daerah untuk menyampaikan Injil keselamatan.

Adapun alas an khotbah-khotbah dalam kebangkitan rohani turut mendorong terjadinya pelayanan misi sebab khotbah-khotbah yang disampaikan oleh para misionaris pada umumnya berpusat pada Injil keselamatan. Mereka hanya berfokus pada Injil kasih karunia dan bukan menyampaikan Injil lain (seperti yang terdapat dalam Galatia 1:6-10). Khotbah yang mereka sampaikan isinya selalu berbicara sekitar kekudusan dan anugerah Allah, manusia berdosa dan keharusan untuk bertobat, Kristus dan karyapenebusan-Nya. Itu sebabnya setiap kali seseorang merenungkan kembali kasih Allah melalui pengorbanan anak-Nya yang tunggal, Yesus Kristus di kayu salib dan bertobat dengan sungguh-sungguh, maka suatu kebangkitan rohani pasti terjadi.

Oleh sebab itu, penulis menutup dan menyimpulkan bagian ini dengan mengutip perkataan Rasul Paulus dalam Roma 10:13-15 yang berbunyi demikian: Sebab, barangsiapa yang berseru kepada nama Tuhan, akan diselamatkan. Tetapi bagaimana mereka dapat berseru kepada-Nya, jika mereka tidak percaya kepada Dia? Bagaimana mereka dapat percaya kepada Dia, jika mereka tidak mendengar tentang Dia. Bagaimana mereka mendengar tentang Dia, jika tidak ada yang memberitakan-Nya? Dan bagaimana mereka dapat memberitakan-Nya, jika mereka tidak diutus? Seperti ada tertulis: "Betapa indahnya kedatangan mereka yang membawa kabar baik!"

\section{Implikasi Bagi Gereja untuk Bermisi dan Bangkit Gereja Misionaris}

Gereja yang memiliki visi terutama adalah Amanat Agung. Gereja hadir di muka bumi digerakkan oleh misi Yesus Kristus. Gereja adalah hasil misi Allah, dan gereja berperan untuk mendorong gerakan misi, sekaligus mengutus misi ke bangsa-bangsa, dan suku-suku bangsa sesuai amanah Yesus Kristus untuk menjadikan semua bangsa muridNya.

\section{Gereja Bangkit untuk Misi Yesus Kristus}

Gereja hadir, dan bangkit dari "tidur" untuk melaksanakan Amanat Agung. Berdoa, dan bersaksi adalah wujud kebangkitan rohani dalam gereja, dan pribadi. Orang percaya sebagai gereja Tuhan keluar dari zona nyaman, dan keluar menjadi saksi Kristusuntuk satu tujuan yaitu misi Yesus Kristus. Kebangkitan rohani dimulai dari umat-Nya, gereja-Nya, dan berdampak keluar bagi orang-orang yang belum percaya.

\section{Rekomendasi Penelitian Lanjutan}

Tulisan ini adalah gagasan awal yang perlu diteliti dengan pendekatan kuantitatif untuk melihat gambaran gereja masa kini dalam pelaksanaan misi, dan kebangkitan rohani yang terjadi di dalam gereja yang membawa dampak terhadap pertumbuhan gereja baik secara kuantitas, dan kualitas. Data-data ini tentunya sudah ada di lapangan (gereja), dan perlu dilakukan penelitian lanjutan. Sampelnya adalah gereja-gereja yang melakukan misi penjangkauan orang-orang yang belum percaya, dan gereja-gereja yan mengalami kebangkitan rohani, dan berdampak terhadap gerakan misi yang lebih luas.

\section{Kesimpulan}

Kesimpulan dari tulisan" Hubungan Antara Misi Dan Kebangkitan Rohani,"maka penulis menarik beberapa kesimpulan sebagai berikut:

Pertama, kebangkitan rohani atau revival tentunya memiliki hubungan dengan misi begitupun sebaliknya. Maksudnya ialah kebangkitan rohani dapat menghidupkan kembali 
gairah untuk bermisi dan misi adalah salah satu langkah yang kongkret yang diwujudnyatakan oleh para misionaris ketika terjadinya kebangkitan rohani. Untuk itu, tanda-tanda yang muncul saat kebangkitan rohani terjadi adalah hati misi ikut di dalamnya.

Kedua, kebangkitan rohani yang sejati hanya terjadi atas kehendak Allah Tritunggal yang kudus, bukan oleh manusia. Manusia hanya sebagai saluran atau perpanjangan tangan Tuhan dalam mempelopori terjadinya kebangkitan rohani. Itu sebabnya misi dan kebangkitan rohani merupakan dua hal yang tidak dapat dipisahkan. Sebab Allah pembuat kebangkitan rohani melakukan kegerakan rohani dalam diri para misionaris sehingga mereka dengan semangat yang berkobar dapat melakukan pelayanan misi.

Ketiga, hubungan antara misi dan kebangkitan rohani ialah kebangkitan rohani membangkitkan semangat bermisi. Hal ini ditandai dengan begitu banyaknya misionaris yang terjun dalam pelayanan misi. Bukan hanya sampai di situ saja, bahkan gerakangerakan misi mulai dibentuk dan dapat dirasakan dampaknya hingga beberapa tahun setelahnya.

Keempat, hubungan antara misi dan kebangkitan rohani adalah melalui doa-doa yang dinaikkan bagi pelayanan misi. Inilah yang merupakan salah satu kunci terjadinya kebangkitan rohani. Contoh konkret yang dapat dilihat dari terjadinya kebangkitan rohani adalah dari doa-doa yang dinaikkan oleh para hambaTuhan bagi pelayanan misi. Melalui doa, setiap kita secara langsung mengasihi orang-orang yang belum terjangkau Injil, bahkan hingga keujung bumi sekalipun. Sejauh Allah mampu menjangkau, demikian pula doa itu. Doa adalah cara terbesar yang dipilih Allah untuk melibatkan kita dalam tindakan-Nya. Maka dari itu jika seseorang rindu melihat kebangkitan rohani terjadi, cara yang paling tepat ialah berdoa bagi pekerjaan misi.

Kelima, selain doa, khotbah dalam kebangkitan rohani turut memotivasi terjadinya suatu pelayanan misi. Bahkan khotbah-khotbah yang disampaikan pada saat kebangkitan rohani terjadi, sebenarnya merupakan bagian dari pelayanan misi. Itu sebabnya, setiap kali seseorang dalam sejarah merenungkan kematian Yesus, suatu kebangkitan rohani pasti terjadi. Setelah itu, diikuti oleh suatu gerakan misi. Untuk itu, jika kita menyelidiki khotbahkhotbah yang disampaikan oleh para misionaris pada saat kebangkitan rohani terjadi, tak lama kemudian setelah itu pasti diikuti oleh terjadinya pelayanan misi.

Keenam, kebangkitan rohani ditandai dengan terjadinya perubahan kehidupan spiritual orang Kristen yang stagnan menjadi mapan. Itu sebabnya dunia ini ada di dalam kebutuhan yang mendesak untuk kebangunan rohani. Saat ini setiap gereja Tuhan perlu berdoa bagi pekerjaan misi terlebih meminta kepada Allah Tritunggal yang kudus sehingga Ia dapat memberi kebangkitan rohani kepada dunia ini secara khusus bagi kehidupan kekristenan saat ini. Yesus berkata: "Akulah kebangkitan dan hidup; barangsiapa percaya kepada-Ku, ia akan hidup walaupun ia sudah mati, dan setiap orang yang hidup dan yang percaya kepada-Ku, tidak akan mati selama-lamanya," (Yohanes 11:25).

\section{Rujukan}

Bosch, David J. Transformasi Misi Kristen: Sejarah Teologi Misi yang Mengubah dan Berubah. Jakarta: GunungMulia, 1997.

Brake, Andrew. Diktat Sejarah Misi. Makassar: STT Jaffray Makassar, 2018. Belum dipublikasikan.

Browning, W. R. F. Kamus Alkitab. Jakarta: BPK GunungMulia, 2007.

Daun, Paulus. Misiologi dalam Perspektif Historikal $\mathcal{E}$ Doktrinal. Jakarta: Serving in Mission, 2015.

“Definisi Kebangunan Rohani.” Diakses 08 Januari 2019. 
http://google.com/amp/s/hanya1percikan.wordpress.com/2014/09/22/definisikebangunan-rohani/amp/?espv $=1$

“Diktat Misiologi." Diakses 08 Januari 2019.

http://stt-oi.ac.id/akademik-163-diktak-misiologi.html

Elbers, Veronika J. Doa dan Misi.Malang: Literatur SAAT, 2010.

Finney, Charles. "Revival Lectures." Diakses 08 Januari 2019.

http://www.whatsaiththescripture.com/Voice/Revival.Lectures.html

Lingga, Hotben. "Sekilas Tentang Revivalisme (Gerakan Kebangunan Rohani) Protestan."

Diakses 08 Januari 2019. http://suarakristen.com/2015/03/02/sekilas-tentangrevivalisme-gerakan-kebangunan-rohani-protestan/

Objantoro, Enggar. "Sejarah dan Pemikiran Kaum Injii Di Tengah-Tengah Perubahan Dan

Tantangan Zaman." Evangelikal: Jurnal Teologi Injili dan Pembinaan Warga Jemaat 1, No. 2 (Juli 2017):129-138.

Ronda, Daniel. Kisah-kisah Misi Singkat Di Berbagai Belahan Dunia. Makassar: Sekolah Tinggi TheologiaJaffray Makassar, 2018.

Shibley, David. Pembaruan Karismatik dan Pekabaran Injil Sedunia. Yogyakarta: Andi, 1993.

Thomas, Norman E. Teks-teks Klasik Tentang Misi Dan Kekristenan Sedunia: Melengkapi Adikarya David Bosch, Transformasi Misi Kristen. Jakarta: GunungMulia, 1998.

Warren, Rick. The Purpose Driven Life. Surabaya: Gandum Mas, 2007.

Wim, Chandra. "The Chronicles of Evangelism: Sebuah Pengantar Historis terhadap Gerakan Evangelikal." Veritas 12, No. 2 (Oktober 2011):185-207.

Woga, Edmund. Dasar-Dasar Misiologi. Yogyakarta: Kanisius, 2002.

Wongso, Peter. Tugas Gereja Dan Misi Masa Kini. Malang: Seminary Alkitab Asia Tenggara, 1996.

Wijaya, Hengki. Analisis Data Kualitatif Ilmu Pendidikan Teologi. Makassar: Sekolah Tinggi Theologia Jaffray Makassar, 2018.

Wright, Christopher J. Misi Umat Allah: Sebuah Teologi Biblika Tentang Misi Gereja. Jawa Timur: LiteraturPerkantas, 2013. 